\title{
AN EGYPTIAN SCARAB FROM SANA'IYE SITE SOUTH OF TAYMA
}

\section{Emad ELSAYYAD}

Department of History and Archaeology, Faculty of Arts, Alexandria University, Alexandria, Egypt E-mail: e.ibrahim@alexu.edu.eg

\section{ABSTRACT}

The Saudi General Department of Antiquities and Museums in 1988 discovered six collective burials at the socalled industrial site "Sanaciye" in Tayma. An Egyptian-style scarab with an inscription of the name of the god Amun was found on the site. The excavation report neglected to study this scarab, its presence in these burials, and its purpose. This scarab was not the only object representing the Egyptian influence, as a Wadjet-eye amulet accompanied it. The report itself has failed to describe and date these objects.

The significance of this study is clarified by historically contextualising the data to identify the function of this scarab. Indeed, in Egypt, this object tended to be used as a seal or as a protection amulet. Both functions are considered as the scarab only bears the signs of the name Amun.

In addition, this paper attempted to determine the scarab's date, identifying it to be the reigns of Ramesses III or his successor at the latest. This reflects the Egyptian presence in the Late Ramesside era, in the northwest of the Arabian Peninsula.

\section{KEYWORDS}

Scarab - Tayma - Arabian Peninsula Ramesses III

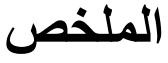

كثفت الإدارة العامة للآثار والمتاحف بالمملكة العربية السعودية في منطقة الصناعية بتيماء عام العام العادية 1988م على مجمو عة من المقابر الجماعية، وكاعة وكان من بين المكتشفات بالموقع جعران ذو ذابر طراز مصري وعليه نقوش تحمل اسم الإله آمون. ولم

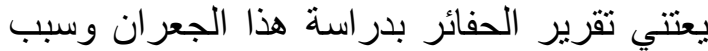

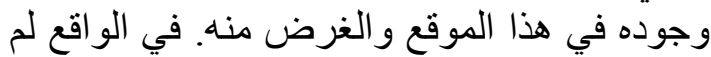
يكن هذا الجعران هو القطعة الأثرية الوحيدة التي التي

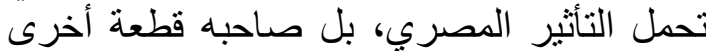
تمثل تميمة عين وجات، إلا أن التقرير نفسه قد أخفق

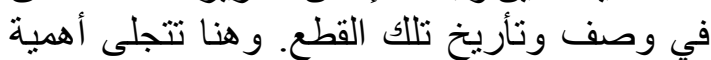
الدر اسة في توظيف بعض المعطبات التاريخية في

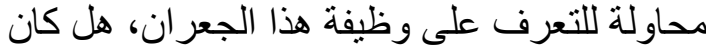

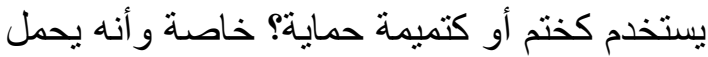
اسم الإله آمون فقط. فضلا عن محاولة التهائة التأريخ الزمني له حيث استتنجت الدراسة الترجيح بأنه ينتمي لعهد الملك رعمسيس الثالث أو خلفه على الثى

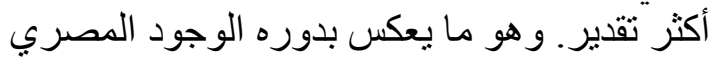
آنذاك في الركن الثمالي الثيلي لغربي من الجزيرة

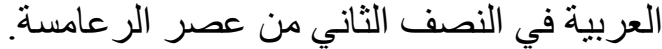

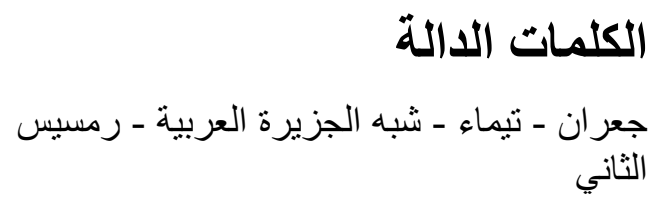
الثاني

\section{INTRODUCTION*}

Tayma Oasis became historically important thanks to its geographic location in the northwest of the Arabian Peninsula. It had become one of the civilised centres in the Arabian 
Peninsula, as it controlled both the internal industry and the exported products and goods coming from the Near East, especially, those of ancient Egypt and Iraq. Also, the historical and cultural importance of Tayma led the Chaldean king Nabonidus to declare it as the capital of his kingdom for ten years. The Assyrians also occupied the oasis before his arrival.

The Egyptian influence in Tayma is attested approximately 100 years before the reign of Nabonidus, from the end of the Late Bronze Age and the beginning of the early Iron Age. It continues to the second half of the first millennium. The attraction for this oasis is due to its geographic location, and its role in ancient trading routes of incense and aromatic woods, to the south of the Arabian Peninsula. This active role of the site within ancient trading may be demonstrated through the original Egyptian objects discovered locally, such as beads, figurines, scarabs, and painted pottery. Among those finds, an Egyptian scarab bore a hieroglyphic inscription on its surface. So far, studies that discussed the intercultural contact between Egypt and the northwest of the Arabian Peninsula have neglected to mention this scarab as well as its historical and cultural importance. ${ }^{1}$ This paper aims to study this scarab by translating and analysing its contact and to determine its timeframe.

\section{DISCOVERY AND DESCRITION}

In 1988 AD (1408 AH), the Saudi General Department of Antiquities and Museums excavated six collective burials in Sanaciye site in Tayma Oasis, located to the northwest of the Arabian Peninsula. They were rectangular, following a local type; one of those contained the aforementioned Egyptian scarab with hieroglyphs (Fig.1). However, the report did not provide a scientific description of the scarab. It further neglected to mention or identify the timeframe this scarab belongs to. This would have been important to determine its historical and cultural significance, as well as its purpose on the site. The report only mentioned that scarabs were used as an ornament, symbolising the sun's strength. It also pointed out that Egyptians used this type of object as seals starting from the Middle Kingdom. ${ }^{2}$ The Sanaciye's scarab simulated the features of traditional Egyptian scarabs made of faience, characterised by their unique blue to green-blue glaze. ${ }^{3}$

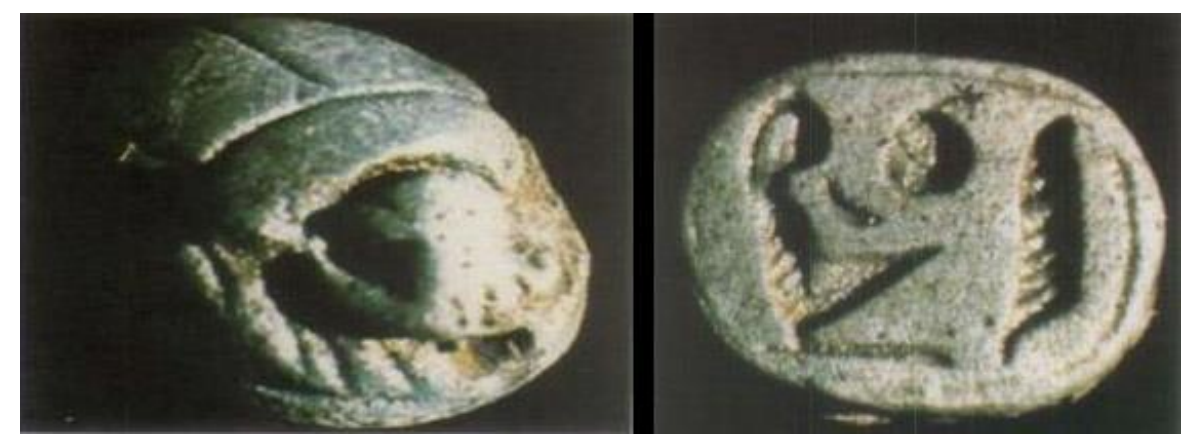

Fig.1: Sanaciye's scarab from Tayma

Abu-Duruk, “A Preliminary Report in the Industrial Site Excavation at Tayma”, Pl.9.

\footnotetext{
* This Paper was proofread by Dr K. Watt of Simbel Proofreading.

${ }^{1}$ Sperveslage, G \& Eichmann, R., 'Egyptian Cultural Impact on North-west Arabia in the Second and First Millennia BC,' PSArabStud 42, London, (2012), 371-384; Sperveslage, G., 'Intercultural Contact between Egypt and Arabian Peninsula at the Turn of the 2nd to the 1st Millennium BCE,' in: García J. C. M. (ed.), Dynamics of Production in the Ancient Near East 1300-500 BC, Oxford, (2016), 303-330; Sultan, S., 'The Exchange of Cultural Relations between Egypt and Hejaz Region during the Second and First Millennia B.C.,' JFTHUSC 3, Issue 2, (2019), 69-87.

2Abu-Duruk, H., 'A Preliminary Report in the Industrial Site Excavation at Tayma: First Season 1987-1408,' Atlal 12, Riyadh, (1989), 14-15.

${ }^{3}$ Kalloniatis, F., The Egyptian Collection at Norwich Castle Museum: Catalogue and Essays, Oxford, (2019), 157.
} 
Egyptian scarabs were used as seals, ornaments or religious amulets and were widely found all over the ancient Near East region. Many examples attest to the existence of those scarabs in ancient Syria, Iraq or in the Arabian Peninsula. This proves the greatly expanded and diversified ancient Egyptian abroad relations. Those relations existed thanks to trading, diplomatic activities, and cultural ones within the Near East. ${ }^{1}$ While most scarabs were recovered in Middle and Late Bronze Age sites, a small but a growing number is assigned to the Iron Age, reflecting Iron Age manufacture. ${ }^{2}$ The majority of these scarabs bear personal names of people and eminent individuals of the time, either kings, queens, royal family members or even officials. These were used mainly as seals. ${ }^{3}$

Regarding Sanaciye site's scarab, it was in the shape of the well-known beetle insect, with hieroglyphs on its flat surface that were read from the right to the left as follows: ${ }^{\odot}$. It starts with the uniliteral sign read as "i", then the ideogram for the sun disk "Ra", then a determinative for the deity. The curved false beard specified its identity to indicate that this relates to one of the deities. ${ }^{4}$

Certain scarabs bear the name of deities. The most common opinion is that scarabs carrying divine names were used as votive amulets to request greetings from the various gods such as Thoth, Horus, Hathor, Amun-Re or Maat. ${ }^{5}$ On the other hand, scarabs bearing inscribed personal names were used as seals and meant to mark the possession and the belonging to someone.

On the contrary, scarabs bearing names of deities were probably used for votive purposes or suspended around the neck as amulets for protection, as demonstrated by physical and artistic evidence. Regarding Sanaciye's scarab, this is supported by its shallow inscription, preventing its use for sealing. Indeed, this would have made it difficult to leave a bold and clean imprint, compared to other seals with deep inscriptions to leave a clear stamp.

Perhaps using precious stones to make some scarabs holding shallow inscriptions made it a means to discriminate between seal and amulet scarabs. ${ }^{6}$

In addition, this scarab was clearly used as an amulet and not for its sealing function, as it was found beside another object, identified for its votive and protective role for the owner: a $w \underline{d} 3 t$ eye, the Horus eye amulet. The report failed to identify it as the team captured an inverted picture for the piece as seen in (Fig.2). It was thus described as a bird head. ${ }^{7}$ However, this is an Egyptian Horus eye, used for protection. As it has a hole on its upper part, it was used as a pendant around the neck. This coincides with the small size of Sanaciye's scarab and with the hole in its upper part, from which it could be hanged.

\footnotetext{
${ }^{1}$ Ben-Tor, D., 'The Historical Implications of Middle Kingdom Scarabs Found in Palestine Bearing Private Names and Titles of Officials,' BASOR 294, New Haven, (1994), 7-22.; Horn., S., 'Scarabs from Schechem,' JNES 21, no.1 (1962), Chicago, 1-14.

2Daviau, 'In the Shadow of a Giant: Egyptian Influence in Transjordan during the Iron Age', in: Harrison T. P \& Banning, E. B \& Klassen, S, (eds.), Walls of the Prince: Egyptian Interactions with Southwest Asia in Antiquity, Essays in Honor of John S. Holladay, Jr. Netherlands, (2015), 237.

3Pier, G., 'Historical Scarab Seals from the Art Institute Collection: Chicago,' AJSL 23, no.1, Chicago, (1906), 75.

${ }^{4}$ Gardiner, A., Egyptian Grammar, 3rd (ed), Oxford, (1957), 446, 40.

${ }^{5}$ Grenfell, A., 'The Scarab Collection of Queen's College: Oxford,' JEA 2, no.4, London, (1915), 228.

${ }^{6}$ Ben-Tor, 'The Historical Implications of Middle Kingdom Scarabs,'7.

${ }^{7}$ Abu-Duruk, 'A Preliminary Report in the Industrial Site Excavation at Tayma,' 15.
} 


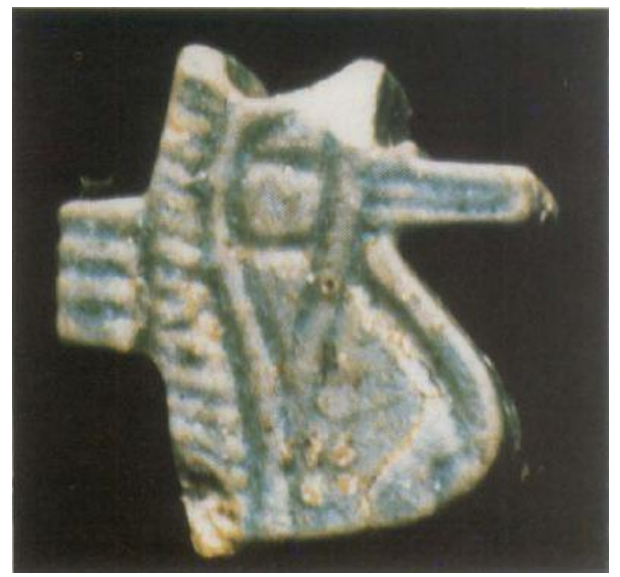

Fig.2: Inverted picture of $w \underline{d} 3 t$ eye which was described as a bird's head in the excavation report. AbuDuruk, "A Preliminary Report in the Industrial Site Excavation at Tayma", Pl.9.

\section{THE INSCRIPTION}

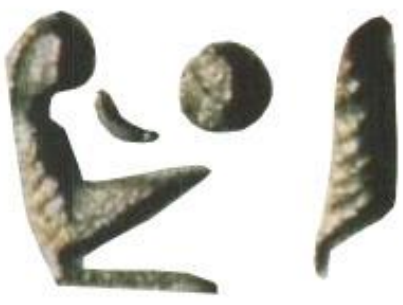

Fig. 3: Details of the inscription on the Scarab

The signs inscribed on the scarab were simplified into three signs read from right to left. The

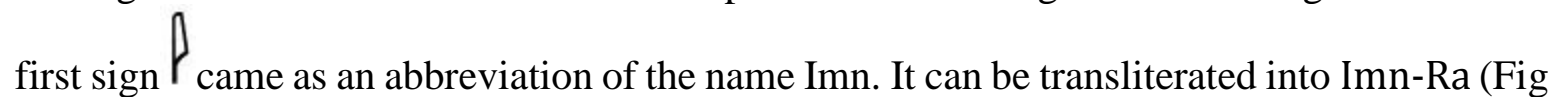
3). However, it was more common to write the deity's name Amun on personal seals and scarabs via the two signs using the first uniliteral sign of its name , then deliberately substituted the biliteral sign of the name of the god שس山س with the determinative of the deity. This substitution may be to highlight the scarab's function as an amulet, as the artist preferred depicting the god's figure instead of using one of the biliteral phonograms of his name.

The abbreviated form of Amun's name in the form of the sign $P$ is not exclusive to Sanaciye's scarab, as it occurred in more instances. One of the closest examples for this name's writing appeared on a scarab in County Museum in Los Angeles, bearing the name of the king Ramesses (Fig. 4), with the name of the god Amun written only with the first uniliteral phonogram of the reed hieroglyph. This style of writing in the ancient Egyptian language is called cryptographic writing. ${ }^{1}$ In another Egyptian scarab discovered in tomb 66 in Bet Shan region in Palestine, the name of the god Amun was written in the same abbreviated style. ${ }^{2}$

${ }^{1}$ Lacovara, P., The World of Ancient Egypt: A Daily Life Encyclopedia, vol.1, ABC-CLIO, (2016), 188.

${ }^{2}$ Oren, E., The Northern Cemetery of Beth Shan, Brill Archive, (1973), 125. no. 4. 


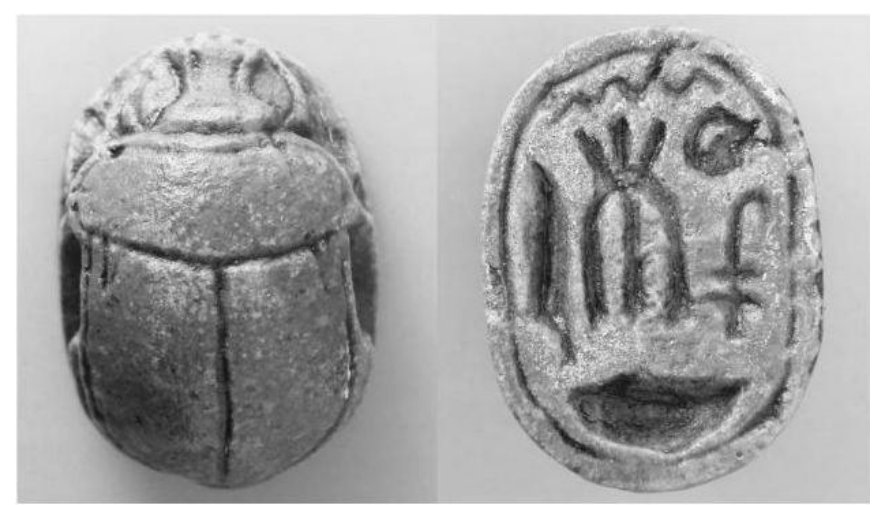

Fig. 4: Ramesside Scarab bearing the abbreviated writing of the god Amun using uniliteral phonogram (I)Lacovara, The World of Ancient Egypt, 188.

The second sign is the distinct sun disc $\odot$, that is read as Ra to create along with the name of the god Amun, the combined form of the two deities as Imn-Ra. This simple writing is commonly found on all types of monuments. The last sign is that of a sitting deity with a false beard.

The inscription's style in the seated deity's sign that came here as a determinative of the god Amun-Ra, differs from the traditional style of inscriptions in Middle Egyptian, ${ }^{1}$ which keep constant rules in inscribing hieroglyphic signs and their details. On the contrary, this is an abbreviated form similar to the signs written in ink, which included fewer details, known as cursive hieroglyphs. ${ }^{2}$

These features of cursive writing appear in the folded legs of the deity, which are typically more vertical in standard inscriptions and meet the base shown similar to the cursive writing, in which the legs' line meets the back's line: $\bar{Z}$. A horizontal line picturing the base was added from it. The cursive is further reflected by the curved false beard depicted away from the deity's head, one of Amun's customary regalia. ${ }^{3}$

\section{DATING THE SCARAB OF SANA'IYE}

Dating Sanaciye's scarab discovered in Tayma requires focusing on three aspects. The first is the writing style of the name of the god Amun, abbreviated with the uniliteral phonogram Although the oldest known abbreviated mention of the name of Amun dates to the $6^{\text {th }}$ Dynasty on amulets, ${ }^{4}$ it was done differently from the present example, in a different style of cryptographic writing. ${ }^{5}$ The present type of abbreviated writing style did not generally appear in inscriptions and scarabs, except in limited examples, all belonging to the Ramesside era, the $19^{\text {th }}$ and $20^{\text {th }}$ Dynasties. $^{6}$

\footnotetext{
${ }^{1}$ Middle Egyptian, sometimes called Classical Egyptian, is closely related to Old Egyptian. It appeared around $2100 \mathrm{BC}$ and survived as a spoken language for some five hundred years, but it remained the standard hieroglyphic language for the rest of ancient Egyptian history. Allen, J., Middle Egyptian: An introduction to the Language and Culture of Hieroglyphs, Cambridge University Press, (2010), 1- 6.

${ }^{2}$ Bleiberg, E., 'Literature,' in: Bleiberg E. (ed.), Arts and Humanities through the Eras: Ancient Egypt 2675332 B.C.E, New York, (2005), 112-149.117.

${ }^{3}$ Ayad, M., God's Wife, God's Servant: The God's Wife of Amun, Routledge, (2009), 135.

${ }^{4}$ Wainwright, G., 'The Origin of Amun,' JEA 49, no.1, London, (1963), 23.

${ }^{5}$ Brunton.,G., MATMAR: British Museum Expedition to Middle Egypt 1929-1931, London, (1948), pl. XXXIII. 14.

${ }^{6}$ Rowe, A., A Catalogue of Egyptian Scarabs, Scaraboids, Seals and Amulets in the Palestine Archaeological Museum, Jerusalem, (1936), 253, P1. XXVIII, 62; Lacovara., The World of Ancient Egypt, 188.
} 
Secondly, the carving style of the determinative of the god Amun was similar to a hand writing style known as cursive hieroglyphic. In addition to the sign's shape and the writing style, this is further seen in the direction of signs themselves, as cursive hieroglyphic was written from the right to the left, ${ }^{1}$ as seen on the scarab. This style was common in the Book of the Dead, written with pens and ink on papyrus rolls in the New Kingdom, and especially the Ramesside era when they became widely common. ${ }^{2}$

Finally, the Egyptian influence in the northwest of the Arabian Peninsula and Tayma oasis has been precisely dated by archaeological evidence to the Early Iron Age (1200-1000 BC), as seen elsewhere in architecture and arts. After finding a building with external and internal fences, the excavators discovered a large collection of funerary material between the two fences. Among these elements of Egyptian minor arts, there is a collection of amulets, scarabs and pottery that are decorated with lotus flowers. These findings reflect the Egyptian presence in this area. ${ }^{3}$

Additionally, on one natural stone located on the western side of Tayma, an inscription carrying two cartouches of king Ramesses III was found in November 2010, accompanied with his titles in the traditional form. This inscription was done in the traditional writing and artistic style of Egyptian hieroglyphs. This proves that Egyptian individuals inscribed it. ${ }^{4}$ The reign of Ramesses III (1188-1156 BC), during the second half of the New Kingdom, is contemporary with evidence of the Egyptian existence in Tayma, dating to the Early Iron Age. This relationship with the region was identified in trade missions to bring aromatic objects used in religious rituals. ${ }^{5}$

One notes that this inscription was appended with the title mry $h k 3$ @ 3 (n) $t 3 n b$, meaning "beloved of the great ruler of the whole land". The great ruler is the god Amun, the principal god in ancient Egypt in the New Kingdom. ${ }^{6} \mathrm{He}$ was often called with this title. ${ }^{7}$

These three arguments indicate that the Egyptian presence in the northwest of the Arabian Peninsula is only attested with material evidence from the time of Ramesses III. As Amun was the principal god in ancient Egypt and all missions were under his supervision and protection, it appears logical that the Sanaciye scarab bore his name. It may be dated to the time of Ramesses III, belonging perhaps to an individual from one of the trade missions, which came through Tayma.

\section{HISTORICAL AND CULTURAL INDICATIONS}

The significance of Sanaciye's scarab is not confined to its artistic and philological aspects. This faience scarab used as an amulet was simple. However, its discovery in such a location makes it also historically and culturally significant, highlighting contemporary relations between Egypt and the northwest of the Arabian Peninsula.

\footnotetext{
${ }^{1}$ Allen, Middle Egyptian, 6.

${ }^{2}$ Laboury, D\& Davies, V., The Oxford Handbook of Egyptian Epigraphy and Palaeography, Oxford University Press, (2020), 587.

${ }^{3}$ Potts, D., A Companion to the Archaeology of the Ancient Near East, John Wiley \& Sons, (2012),828; more details of these different collection see: Hausleiter, A., 'L'Oasis de Taymâ,' in: Ghabban, A and others (eds.), Routes d'Arabie: Archéologie et histoire du Royaume d'Arabie Saoudite, Catalogue d'exposition, Paris, (2010), 231.

${ }^{4}$ Somaglino, C \&Tallet, P., 'Une mystérieuse route sud-orientale sous le règne de Ramses III,' BIFAO 111, Le Caire, (2011), 362.

${ }^{5}$ Luciani, M., 'Mobility, Contacts and the Definition of Culture(s) in New Archaeological Research in Northwest Arabia,' in: The Archaeology of North Arabia: Oases and Landscapes, Proceedings of the International Congress held at the University of Vienna, Austria, 5-8 December (2013), 29

${ }^{6}$ Sperveslage., 'Intercultural Contact between Egypt and Arabian Peninsula,' 309.

${ }^{7}$ Leitz, Ch., Lexikon der ägyptischen Götter und Götterbezeichnungen, V, Louvain, (2002), 500.
} 
This scarab was discovered within remains in the necropolis area in Sanaciye, ${ }^{1}$ suggesting that this amulet may have belonged to a deceased in one of these burials. It may thus indicate a grave that belonged to an Egyptian in Tayma. On the other hand, the material culture of an Egyptian style is not direct evidence to determine the nationality of its owner. A local from Tayma, may have obtained these objects through trade and preserved some Egyptian products.

In order to disprove this last possibility, it is important to mention that this scarab was found in the necropolis, indicating that the owner insisted on being buried with the amulet to be blessed with the name of the god Amun. He may have been asking for his protection. He was accompanied by all his tools and ornaments, which he wished to take in the otherworld. Perhaps, asking the god Amun for protection at the time was not strange. It may be supported by the inscription of king Ramesses III at this location praising the god Amun as his protector. $^{2}$

The other piece of ornament made of faience was also in an Egyptian style, the Horus's eye $w D A t$, also used as an amulet for protection (Fig. 5). ${ }^{3}$ It is the opinion of the author that these objects were used for religious and votive purposes, not as Egyptian souvenirs.

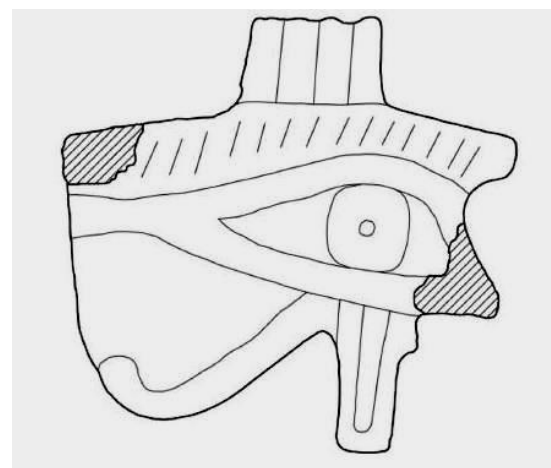

Fig.5: Amulet of WDAt found beside Sanaciye's scarab (Sperveslage, "Intercultural Contact between Egypt and Arabian Peninsula", 317, fig. 14.9)

These findings suggest that this burial belonged to an individual of an Egyptian origin, probably one of the merchants accompanying a trade mission during the reign of Ramesses III, who suddenly passed away while in Tayma oasis. Another possibility is that it was an Egyptian merchant established in Tayma oasis, acting as an intermediary to the recurring trading activities within the Arabian Peninsula via the Sinai desert, ${ }^{4}$ who passed away in the oasis. However, the author supports the first hypothesis due to the burying process having been performed in a perfunctory manner, as he was not buried in an individual tomb; according to the excavation's report, he was buried in a collective tomb. ${ }^{5}$ For this reason, a sudden death seems plausible, justifying his burial in a collective one. In addition, microscopic analysis on items of the Egyptian style material culture found in the same archaeological layers than the Sanaciye's scarab indicate that these objects were manufactured in Egypt, rather than locally. ${ }^{6}$

On the other hand, a burial that belongs to an Egyptian person in a collective tomb in a foreign land points to a very significant social indication, reflecting the harmony between the two

\footnotetext{
${ }^{1}$ Abu-Duruk, 'A Preliminary Report in the Industrial Site Excavation at Tayma,'15.

${ }^{2}$ Riemer, H., Desert road archaeology in ancient Egypt and beyond, Heinrich-Barth-Institut, (2013),512.

${ }^{3}$ Sperveslage, 'Intercultural Contact between Egypt and Arabian Peninsula,' 317.

${ }^{4}$ Paprocki, M., Roads in the Deserts of Roman Egypt: Analysis, Atlas, Commentary, Oxford, (2019), 131.

${ }^{5}$ Abu-Duruk, 'A Preliminary Report in the Industrial Site Excavation at Tayma,' 14.

${ }^{6}$ Sperveslage \& Eichmann, 'Egyptian Cultural Impact,'373.
} 
peoples. As there was no apartheid between the Egyptians or the Tayma's people, none of them refused to bury this body next to the others. Indeed, death and burying for the ancient Egyptians had rules and customs that cannot be neglected, affecting the fate of the deceased in his otherworld.

The archaeological indications have proven the expansion of the regional trading activity and the Egyptian presence in Tayma at the time of Ramesses III. Although the human settlement in Tayma is stated to date from the third millennium BC, the Egyptian findings of scarabs and figurines of various deities did not appear until the time of king Ramesses III and the following rulers. This king established trading stations throughout the caravans' road heading to the south of the Arabian Peninsula, later named the incense road. ${ }^{1}$ It was usually mandatory in these stations to have Egyptian personnel; their duty was to supervise the administration and take care of supplies and other eventualities. ${ }^{2}$ One of these stations was Tayma, an important trading centre where Egyptians brought aromatics, oils, and precious stone such as turquoise. ${ }^{3}$ The Egyptian archaeological remains were related to these men.

\section{CONCLUSION}

The Egyptian presence in Tayma oasis went through two phases: the first one during the reign of Ramesses III, represented in Tayma by the mining campaigns in Sinai, and his urge to control the trading road heading to the south. The second phase dates to the $26^{\text {th }}$ Dynasty, in the second half of the first millennium BC. The findings in this phase were characterised by local manufacturing with an Egyptian style, reflecting the cultural impact of the Egyptian civilisation detected locally.

The relations between Egypt and the northwest of the Arabian Peninsula in the late Ramesside era were not temporary, relying solely on trade missions. The region served as a residence for many Egyptians who were settled there to regulate the trading business and follow up with trading caravans' movements.

The present study clarified that Sanaciye's scarab dates to the reign of king Ramesses III, who was keen on expanding his power and influence on the trading road that passed through Tayma. These trading stations were established as resting points for passing caravans. This is inferred from the Egyptian findings in the necropolis, marked by religious features. It suggests that there were Egyptians who lived for a time in Tayma and integrated within the oasis community, to the extent they were allowed to be buried beside them in mass graves. The inscription carries the name of the god Amun-Ra, who was extremely popular and appreciated by the rulers, inside and outside the Egyptian borders. The artist who made the inscription of Ramesses III pointed out one of the titles of the god Amun, which is "the great ruler" hkj 3 and described the king as the god's beloved. The owner of the scarab decided to be buried with an amulet carrying the same god's name as protection.

Sanaciye's scarab may be considered a protective amulet, tied around the neck with a band, not being used as a seal as it was common for scarabs. It bore the name of a deity with its ideogram determinative rather than a personal name. It was not deemed appropriate to stamp with the name of the god Amun, except one of his priests. This is highlighted by the shallow engraving technique that does not fulfil the requirement for a clear seal impression.

\footnotetext{
${ }^{1}$ Riemer, Desert road archaeology, 515-516.

${ }^{2}$ Sperveslage \& Eichmann, 'Egyptian Cultural Impact,'376.

${ }^{3}$ Eichmann, R., 'Tayma: Oasis and Trade Center on the Frankincense Caravan Route', Adumatu 17, Riyadh, (2008), 17.
} 


\section{BIBLIOGRAPHY}

1- Abu-Duruk, H., 'A Preliminary Report in the Industrial Site Excavation at Tayma: First Season 1987-1408,' Atlal 12, Riyadh, (1989), 9-19.

2- Allen, J., Middle Egyptian: An introduction to the Language and Culture of Hieroglyphs, Cambridge University Press, (2010).

3- Ayad, M., God's Wife, God's Servant: The God's Wife of Amun, Routledge, (2009).

4- Ben-Tor, D., 'The Historical Implications of Middle Kingdom Scarabs Found in Palestine

Bearing Private Names and Titles of Officials,' BASOR 294, New Haven, (1994), 7-22.

5- Bleiberg, E., 'Literature,' in: Bleiberg E. (ed.), Arts and Humanities through the Eras: Ancient Egypt 2675-332 B.C.E, New York, (2005), 112-149.

6- Brunton, G., MATMAR: British Museum Expedition to Middle Egypt 1929-1931, London, (1948).

7- Daviau, M., 'In the Shadow of a Giant: Egyptian Influence in Transjordan during the Iron Age,' in: Harrison T. P \&, Banning E. B \& Klassen S, (eds.), Walls of the Prince: Egyptian Interactions with Southwest Asia in Antiquity, Essays in Honor of John S. Holladay, Jr. Netherlands, (2015), 234-273.

8- Eichmann, R., 'Tayma: Oasis and Trade Center on the Frankincense Caravan Route,', Adumatu 17, Riyadh, (2008), 17-26.

9- Gardiner, A., Egyptian Grammar, 3rd (ed), Oxford, (1957).

10- Grenfell, A., 'The Scarab Collection of Queen's College: Oxford,'JEA 2, no.4, London, (1915), 217-228.

11- Hausleiter, A., 'L'Oasis de Taymâ,' in: Ghabban, A et al. (eds.), Routes d'Arabie: Archéologie et histoire du Royaume d'Arabie Saoudite, Catalogue d'exposition, Paris, (2010).

12- Horn, S., 'Scarabs from Schechem,' JNES 21, no.1, Chicago, (1962), 1-14.

13- Kalloniatis, F., The Egyptian Collection at Norwich Castle Museum: Catalogue and Essays, Oxford, (2019).

14- Laboury, D\& Davies,V., The Oxford Handbook of Egyptian Epigraphy and Palaeography, Oxford University Press, (2020).

15- Lacovara, P., The World of Ancient Egypt: A Daily Life Encyclopedia, vol.1, ABC-CLIO (2016).

16- Leitz, Ch., Lexikon der ägyptischen Götter und Götterbezeichnungen, V, Leuven, (2002). 17- Luciani, M., 'Mobility, Contacts and the Definition of Culture(s) in New Archaeological Research in Northwest Arabia,' in: The Archaeology of North Arabia: Oases and Landscapes, Proceedings of the International Congress held at the University of Vienna, Austria, 5-8 December (2013), 21-56.

18- Oren, E., The Northern Cemetery of Beth Shan, Brill Archive, (1973).

19- Paprocki, M., Roads in the Deserts of Roman Egypt: Analysis, Atlas, Commentary, Oxford, (2019).

20- Pier, G., 'Historical Scarab Seals from the Art Institute Collection: Chicago,' AJSL 23, no.1, Chicago, (1906), 75-94.

21- Potts, D., A Companion to the Archaeology of the Ancient Near East, John Wiley \& Sons, (2012).

22- Riemer, H., Desert road archaeology in ancient Egypt and beyond, Heinrich-BarthInstitut, (2013).

23- Rowe, A., A Catalogue of Egyptian Scarabs, Scaraboids, Seals and Amulets in the Palestine Archaeological Museum, Jerusalem, (1936).

24- Somaglino, C \&Tallet, P., 'Une mystérieuse route sud-orientale sous le règne de Ramses III,' BIFAO 111, Le Caire, (2011), 361-369. 
25- Sperveslage, G\& Eichmann, R., 'Egyptian Cultural Impact on North-west Arabia in the Second and First Millennia BC,' PSArabStud 42, London, (2012), 371-383.

26- Sperveslage, G., 'Intercultural Contact between Egypt and Arabian Peninsula at the Turn of the 2nd to the 1st Millennium BCE,' in: García J. C. M. (ed.), Dynamics of Production in the Ancient Near East 1300-500 BC, Oxford, (2016), 303-330.

27- Sultan, S., 'The Exchange of Cultural Relations between Egypt and Hejaz Region during the Second and First Millennia B.C.,' Journal of the Faculty of Tourism and HotelsUniversity of Sadat City3, Issue 2, (2019), 69-87.

28- Wainwright, G., 'The Origin of Amun,' JEA 49, no.1, London, (1963), 21-23. 